\title{
Silicon accumulation in rice plant aboveground biomass affects leaf carbon quality
}

Jörg Schaller ${ }^{1}$, Robin Heimes ${ }^{1}$, Jian Feng $\mathrm{Ma}^{2}$, Jean-Dominique Meunier ${ }^{3}$, Ji Feng Shao ${ }^{2}$, Miho Fujii-Kashino ${ }^{2}$, and Klaus Holger Knorr ${ }^{4}$

${ }^{1}$ Environmental Geochemistry, Bayreuth Center for Ecology and Environmental Research (BayCEER), University Bayreuth, Universitätsstraße 30, 95447 Bayreuth, Germany

${ }^{2}$ Institute of Plant Science and Resources, Okayama University, Chuo 2-20-1, Kurashiki, 710-0046 Japan

${ }^{3}$ Aix Marseille Univ, CNRS, IRD, Coll. France, INRA, CEREGE, Europôle Mediterranéen de l'Arbois BP 8013545 Aix-en-Provence, cedex 4, France

${ }^{4}$ Ecohydrology \& Biogeochemistry Group, Institute of Landscape Ecology, University Münster, Heisenbergstr. 2, 48149 Münster, Germany

* Correspondence and requests for materials should be addressed to J.S. (Joerg.Schaller@unibayreuth.de) 


\begin{abstract}
Background and aim Silicon is known to be able to substitute carbon in plant biomass, especially in cellulose, lignin and phenols. However, a more comprehensive picture regarding the effect of silicon accumulation on plant carbon quality (cellulose, lignin, phenol, wax, lipids, and free organic acids content) with regard to potential decomposability is still missing.

Methods Two different rice varieties (French brown and red rice cultivars) were cultivated under five different soil silicon availabilities. After maturity we harvested the plants and analyzed them regarding carbon quality by FTIR spectroscopy and regarding plant silicon concentrations.

Results Silicon accumulation was found to be dependent on silicon availability and on the specific rice cultivar. The lowering of carbon compounds content by silicon was found not to be restricted to cellulose, lignin and phenol. Silicon accumulation was able to decrease other carbon compounds such as fat, wax, lipids, and free organic acids, too.

Conclusions Consequently, silicon is important for the carbon quality of silicon accumulating plants. Furthermore, silicon accumulation in plants is interfering with a large range of different carbon compounds potentially altering the leaf economic spectra, decomposability, and thus potentially interfering with the whole performance of ecosystems dominated by silicon accumulating plant species.
\end{abstract}

Keywords: carbon compounds, carbon quality, rice pigmentation, rice plant tissues, silica, silicon 


\section{Introduction}

Rice (Oryza sativa L.) is the main staple food for about half of the world's population (Zhu et al. 2008). Especially in poor regions of the world the daily energy consumption relies mainly on rice (Ninno and Dorosh 2001). Normal rice plant physiology requires silicon (Si) during plant growth (Broadley et al. 2012). Silicon is taken up from soil solution mainly as silicic acid [Si(OH) 4 (Ma et al. 2006), an uncharged monomeric molecule, whereas in aboveground biomass silicic acid polymerizes to different forms of amorphous silica with a higher condensation state (Schaller et al. 2013). The accumulation of Si by plants depends on soil Si availability ((Schaller et al. 2012b; Neu et al. 2017)), the specific plant cultivar ( $\mathrm{Li}$ et al. 2014) and is closely related to plant transpiration (Ma and Takahashi 2002).

It was shown that $\mathrm{Si}$ content is negatively related to carbon contents in aboveground biomass of plants (Neu et al. 2017; Klotzbücher et al. 2018). It was also found that Si content affects the carbon quality of aboveground plant biomass. Silicon content seems to be negatively related to plant phenol content (Schaller et al. 2012a), is both either increasing or decreasing plant cellulose content (Schoelynck et al. 2010; Schaller et al. 2012a), depending on species, and has negative or no obvious effect on plant lignin content (Schoelynck et al. 2010; Schaller et al. 2012a; Klotzbücher et al. 2018).

As cellulose for example is built from sugar monomers or disaccharides (Richmond 2000), a decrease of cellulose formation due to increasing Si content may increase the sugar content of aboveground biomass or increase the amount of other carbon compounds, because these carbon compounds require sugars for their synthesis e.g. fatty acids (Rawsthorne 2002) as important compound for e.g. plant wax formation (Samuels et al. 2008). However, results of Si effects on a broader range of plant carbon compounds are still missing, yet.

To systematically evaluate effects of $\mathrm{Si}$ on plant carbon quality in rice, we thus grew two different rice varieties (the French red rice TamTam and one of the most commonly grown non-pigmented brown rice varieties in France (Arelate)) in climate-controlled chambers under different Si availabilities to examine differences between $\mathrm{Si}$ uptake and corresponding leaf carbon quality. We knew from preliminary screening that the red rice is accumulating more arsenic compared with the brown rice (Eberle 2015). We deduced from this information that the red rice may have higher requirements for $\mathrm{Si}$ compared with the brown rice, because under flooded growing conditions arsenic is present as arsenite which is taken up by plant root via the Si uptake pathway (Meharg and Meharg 2015). Our hypotheses were therefore that (i) $\mathrm{Si}$ accumulation will be lower for the brown rice compared to the red rice and (ii) Si content is affecting plant carbon quality in the rice aboveground biomass by reducing the concentration of specific carbon compounds such as phenols or cellulose by Si compounds. Thereby, plant carbon quality was assessed using Fourier-transformed infrared spectroscopy (FTIR) (Niemeyer et al. 1992; da Luz 2006). Additionally, we analyzed the Si transporter expression in rice seedlings in a separate experiment, to check whether potential differences in $\mathrm{Si}$ content between the used rice cultivars can be related to differences in expression of Si transporter. 


\section{Material and Methods}

\section{Seeds}

Seeds for Si transporter gene expression analysis in hydroponic culture and the seeds for the rice cultivation experiment were obtained from the Centre Français du Riz (CFR) in Arles, France.

\section{Si transporter gene expression analysis}

To determine the expression of Si transporter genes, seedlings were cultivated hydroponically as described previously (Ma et al. 2002). All experiments were conducted in a greenhouse at $25{ }^{\circ} \mathrm{C}$ with natural light and a replication of three. Rice seedlings (18 days old) were exposed to a nutrient solution containing $0,0.2$ or $2 \mu \mathrm{M}$ arsenite. Arsenite is an analog for silicic acid, both being uncharged and taken up via the same transport pathways, the LSi1 and LSi2 transport systems (Ma and Yamaji 2015). The solution was changed every two days. After 1-week exposure, the roots were sampled for RNA extraction. Total RNA was extracted from the roots using the RNeasy Plant Mini Kit (Qiagen). For conversion to cDNA, $0.5 \mu \mathrm{g}$ of total RNA was used, following the protocol supplied by the manufacturers of SuperScript II (Invitrogen). Specific cDNAs were amplified by So Fast EvaGreen Supermix (Bio-Rad). Quantitative real-time PCR was performed with the primers shown in Supplementary Table 1. Actin was used as an internal standard.

\section{Rice plant cultivation}

For the rice cultivation experiments, the red cultivar TamTam and the brown cultivar Arelate were grown in phyto chambers (Thermotec, Weilburg, Germany) at a 12-hour day/night cycle $\left(30{ }^{\circ} \mathrm{C}, 70 \%\right.$ $\mathrm{RH}$, about $1000 \mu \mathrm{M} \mathrm{m}^{2} \mathrm{~s}^{-1}$ light intensity from sodium vapor lamps at day and $18{ }^{\circ} \mathrm{C}, 80 \% \mathrm{RH}$ and zero light at the night) during germination. About 25 rice seeds were seeded on $3.5 \mathrm{~kg}$ homogenized

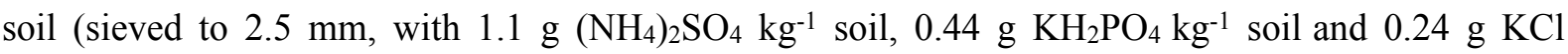
$\mathrm{kg}^{-1}$ soil added, in plastic containers) from Camargue (from the test fields at CFR). After germination the seedlings were reduced to 15 per pot. To measure dissolved and some of the exchangeable Si from soils we used a sodium acetate extraction according to Sauer et al. (2006), because this method was shown to correlate well with Si uptake by rice (Snyder 2001). In short, $5 \mathrm{~g}$ of soil were extracted with $50 \mathrm{~mL}$ sodium acetate, adjusted to $\mathrm{pH}=4$ for $5 \mathrm{~h}$ at $40^{\circ} \mathrm{C}$. The extracts were filtered $(0.2 \mu \mathrm{m}$ cellulose acetate) and analyzed for Si by inductively coupled plasma optical emission spectrometry (ICP-OES). Silicon was added to the soil as synthetic amorphous silica (Aerosil 300, Evonik Industries AG, Germany) at five concentrations, 0 (control), 1 (Si1), 5 (Si5), 10 (Si10) and 50 g amorphous silica 
$\mathrm{kg}^{-1}$ soil (Si50), each in five replicates for both varieties, equaling 50 pots in total. The soils were premoistened with $1.5 \mathrm{~L}$ tap water (Bayreuth). Containers with red and brown rice plants were placed randomly in the chambers because cross-pollination was assumed to be low. During germination, the water levels were kept constant at $3-4 \mathrm{~cm}$ above the soil. After germination, the water levels were kept constant at $10 \mathrm{~cm}$ above the soil. Tap water was stored in plastic cans in the chambers to assure that the water temperature was appropriate for the plants. The Si concentration in tap water was $\sim 3 \mathrm{mg} \mathrm{L}^{-1}$. After germination, the climate was changed to a constant temperature and humidity of $21{ }^{\circ} \mathrm{C}$ and $80 \% \mathrm{RH}$, respectively. We took pore water samples for the analysis of the available $\mathrm{Si}$ at six different time points over the whole growth period using suction samplers (Rhizon, Rhizosphere Research, Eijkelkamp, The Netherlands; see SI for details).

\section{Harvest and post treatment}

Plants were harvested at maturity ( $\sim 150$ days after seeding) when completely dried, 14 days after the last irrigation. Plants were cut off about $2 \mathrm{~cm}$ above the soil, separated into whole grain, husk, flag leaf, flag leaf sheath and leaf, weighed and dried at $75^{\circ} \mathrm{C}$ for 3 days in paper bags. Flag leaves, flag leaf sheaths, leaves (all leaves other than the flag leaf), and husks were grinded in an ultra-centrifugal mill (Retsch, ZM1, $10000 \mathrm{r} / \mathrm{min}, 0.12 \mathrm{~mm}$, Germany). All tissues were stored dark at room temperature until analysis.

\section{Analysis}

Si was extracted from plant samples by an alkaline digestion where $30 \mathrm{mg} \pm 1 \mathrm{mg}$ of each sample were weighed into extraction vials, filled up with $30 \mathrm{~mL} 1 \% \mathrm{Na}_{2} \mathrm{CO}_{3}$ and treated $5 \mathrm{~h}$ at $85{ }^{\circ} \mathrm{C}$ in a heating block (DeMaster 1981; Meunier et al. 2014). Samples were filtered through $0.2 \mu \mathrm{m}$ cellulose acetate filters and stored at room temperature until analysis with inductively coupled plasma optical emission spectrometry (ICP-OES).

\section{FTIR analysis}

FTIR spectra from leaves (all leaves other than the flag leaf) were obtained using a Cary 660 FTIR spectrometer (Agilent, Santa Clara, CA, USA). An amount of $2 \mathrm{mg}$ of finely ground sample was mixed with $200 \mathrm{mg} \mathrm{KBr}$ (FTIR grade, Sigma Aldrich, St. Louis, MO, USA) and analyzed as a $13 \mathrm{~mm}$ pellet. A total of 32 scans were collected for each sample and averaged, a $\mathrm{KBr}$ background was subtracted, and a baseline correction was applied prior to further evaluation. Relative peak intensities and organic matter functional moieties were interpreted following existing studies (Niemeyer et al. 1992; da Luz 2006; Agethen and Knorr 2018; Hodgkins et al. 2018) and as listed in Table 1. We focused on wavenumbers indicative of aliphatics, waxes $\left(2,850\right.$ to $\left.2,920 \mathrm{~cm}^{-1}\right)$, of organic acids, 
oxygenated compounds $\left(\sim 1,710 \mathrm{~cm}^{-1}\right)$, of aromatics, proteinaceous compounds (I) $\left(1,650 \mathrm{~cm}^{-1}\right)$, of lignin, organic acids $\left(1265,1450\right.$, and $\left.1515 \mathrm{~cm}^{-1}\right)$, and of proteinaceous compounds (II) $\left(1550 \mathrm{~cm}^{-1}\right)$.

Table 1. Assignment of absorption bands assessed by Fourier-Transformed Infrared Spectroscopy (FTIR).

\begin{tabular}{|c|c|c|c|}
\hline Wavenumber, cm-1 & Assignment & Compound class & Reference \\
\hline 2920 & Antisymmetric $\mathrm{CH} 2$ & wax, lipid & $\begin{array}{l}\text { (Niemeyer et al. 1992; } \\
\text { Cocozza et al. 2003) }\end{array}$ \\
\hline 2850 & Symmetric $\mathrm{CH} 2$ & Wax, lipid & $\begin{array}{l}\text { (Niemeyer et al. 1992; } \\
\text { Cocozza et al. 2003) }\end{array}$ \\
\hline 1710 & $\mathrm{C}=\mathrm{O}$ stretch of $\mathrm{COOH}$ & Carboxylic acids & (Niemeyer et al. 1992) \\
\hline 1653 & $\mathrm{C}=\mathrm{O}$ of amides & $\begin{array}{l}\text { Prote in a c e us } \\
\text { compounds }\end{array}$ & $\begin{array}{l}\text { Artz et al. 2008; } \\
\text { Agethen and Knorr } \\
2018)\end{array}$ \\
\hline $1650-1600$ & $\begin{array}{l}\text { A rom at ic } \mathrm{C}=\mathrm{C} \\
\text { stretching; } \mathrm{C}-\mathrm{O} \text { in } \\
\mathrm{COOH}\end{array}$ & $\begin{array}{l}\text { Lignin and other } \\
\text { aromatics, carboxylates }\end{array}$ & (Niemeyer et al. 1992) \\
\hline 1550 & $\mathrm{~N}-\mathrm{H}$ in-plane vibration & $\begin{array}{l}\text { Prote in a c e o u s } \\
\text { compounds }\end{array}$ & $\begin{array}{l}\text { Artz et al. 2008; } \\
\text { Agethen and Knorr } \\
\text { 2018) }\end{array}$ \\
\hline 1515 & $\begin{array}{l}\text { A rom at ic } \quad \mathrm{C}=\mathrm{C} \\
\text { stretching }\end{array}$ & $\begin{array}{l}\text { Lignin, phenolics, } \\
\text { aromatics }\end{array}$ & $\begin{array}{l}\text { (Niemeyer et al. 1992; } \\
\text { Cocozza et al. 2003) }\end{array}$ \\
\hline 1450 & $\begin{array}{l}\text {-CH deformation and - } \\
\mathrm{CH} \text { bending }\end{array}$ & Lignin and aliphatics & (Niemeyer et al. 1992) \\
\hline 1265 & $\begin{array}{l}\mathrm{C}-\mathrm{O} \text { stretching of } \\
\text { phenolic } \mathrm{OH}\end{array}$ & Lignin & (Niemeyer et al. 1992) \\
\hline 1100 & $\begin{array}{l}{\left[\mathrm{SiO}_{4}\right] \text { asymmetric }} \\
\text { stretching }\end{array}$ & (biogenic) silicates & $\begin{array}{l}\text { (Meyer-Jacob et al. } \\
2014 \text {; Vogel et al. } \\
\text { 2016) }\end{array}$ \\
\hline $1080-1030$ & $\begin{array}{l}\mathrm{C}-\mathrm{O} \text { stretching and } \mathrm{O}- \\
\mathrm{H} \text { deformation }\end{array}$ & Polysaccharides & (Niemeyer et al. 1992) \\
\hline$<1000$ & Si-OH vibration & (biogenic) silicates & $\begin{array}{l}\text { (Meyer-Jacob et al. } \\
\text { 2014; Vogel et al. } \\
\text { 2016) }\end{array}$ \\
\hline
\end{tabular}

\section{Statistical analysis}

An ANOVA was performed for comparison of the data followed by a Tukey-HSD post hoc test using SPSS (version 20.1). 


\section{Results}

\section{Silicon in soil, porewater and plant tissues}

Initially plant-available (sodium acetate extractable) $\mathrm{Si}$ in the used soils was $64.5 \pm 3.2 \mathrm{mg} \mathrm{Si} \mathrm{kg}^{-1} \mathrm{DW}^{-1}$. In the pore water, $\mathrm{Si}$ availability for the control, the $\mathrm{Si}-1$, and the $\mathrm{Si}-5$ treatment dropped remarkably after mid of July at the beginning of the reproductive phase for both varieties. Final concentrations in pore water were as low as $0.215 \mathrm{mg} \mathrm{L}^{-1}$ (Fig. S2). For the Si-50 treatment, concentrations were $\geq 25 \mathrm{mg} \mathrm{L}^{-1}$ over the whole growth period but the decrease during the reproductive phase was stronger for brown than red rice. At the end of July, Si concentrations reincreased to about $45 \mathrm{mg} \mathrm{L}^{-1}$ in brown rice, indicating a decreased uptake in brown rice at this stage. For red rice, the concentrations remained constantly high at about $40 \mathrm{mg} \mathrm{L}^{-1}$ irrespective of the growth stage, indicating an overall lower Si uptake.

The most striking result from the Si concentration data was that brown rice accumulated significantly $(p<0.001, F=70,632$, ANOVA) more Si in all tissues over all Si treatments compared with the red rice (Fig. 1). Tukey-HSD post hoc revealed significant differences between red and brown rice for the Si treatments (Fig. 1). The differences were most pronounced in the flag leaves (Si-50) (Fig. 1a), with around $100 \pm 12$ and $50 \pm 17 \mathrm{mg} \mathrm{g}^{-1} \mathrm{DW}^{-1}$ in brown rice and red rice, respectively. The same holds true for the husk, where brown rice accumulated about $50 \%$ more $\mathrm{Si}$ in each treatment compared with red rice, including the control (Fig. 1d). Furthermore, the difference between red and brown rice husk Si concentrations was always roughly the same in absolute numbers for all Si treatments. There were no significant differences between red and brown rice in the flag leaf sheath (Fig. 1b) and the leaf (Fig. 1c). In all analyzed tissues, Si concentrations increased significantly ( $p<0.001, F=228,937$, ANOVA) with Si treatments (except for Si-1) for both varieties (Fig. 1). Si concentrations in the grains were below the detection limit. In the other tissues, Si concentrations followed the decreasing order husk $>$ flag leaf $>$ flag leaf sheath $>$ leaf.

\section{Silicon transporter gene expression analysis}

No significant differences were found between the pigmented red rice and the non-pigmented brown rice (LSi $F$ 0.083, $p=0.777$; LSi2 $F$ 0.085, $p=0.775$; LSi3 $F$ 0.413, $p=0.529$; LSi6 $F 0.339, p=0.529$ ) regarding the expression levels of the different Si transporters for 14 day old plants (Fig. S1).

\section{Silicon effects on leaf carbon quality}

Silicon fertilization seemed to affect the quality of plant carbon in rice leaves as indicated by FTIR (Fig. 2, Table 1). With increasing Si availability (from control to Si-50) the absorbance at 2,850 to $2,920 \mathrm{~cm}^{-1}$ (aliphatics, waxes), at $\sim 1,710 \mathrm{~cm}^{-1}$ (organic acids, oxygenated compounds), at $1,650 \mathrm{~cm}^{-1}$ 
(aromatics, proteinaceous compounds), at 1265, 1450, and $1515 \mathrm{~cm}^{-1}$ (lignin, organic acids), and at $1550 \mathrm{~cm}^{-1}$ (proteinaceous compounds) was reduced compared to absorbance at $1090 \mathrm{~cm}^{-1}$ (Fig. 2, Fig. S3). This indicates a shift in carbon quality towards a relatively higher share of carbohydrates and relatively lower share of lignin, proteinaceous compounds, and waxes under Si fertilization; according to the higher Si uptake of brown rice, spectral changes were more pronounced for brown rice compared to red rice. Moreover, we found a broadening of the shoulder at $1,100 \mathrm{~cm}^{-1}$ and a more pronounced peak at around $800 \mathrm{~cm}^{-1}$, presumably both indicative of higher biogenic silica contents at increased Si fertilization; again, these features were also more pronounced for brown rice, taking up more Si. Overall, we found no clear significant effect of the Si availability on the carbohydrate content (Fig. S4) for both the red $(d f=4, F=2.337, p=0.092)$ and the brown rice leaves $(d f=4, F=2.026$, $p=0.126$ ). But we found a strong significant effect of the $\mathrm{Si}$ availability on the aromatics content (Fig. S4) for both the red $(d f=4, F=14.543, p<0.001)$ and the brown rice leaves $(d f=4, F=22.873$, $p<0.001)$. Variety (red or brown rice) had also a significant effect on both carbohydrate $(d f=1$, $F=4.118, p=0.049)$ and aromatics $(d f=1, F=25.059, p<0.001)$ content (Fig. S4).

\section{Discussion}

Our experiment revealed that $\mathrm{Si}$ fertilization led to a strong increase in the rice tissue Si content for brown as well as for red rice. This effect has been well documented for rice before (Bogdan and Schenk 2008) and also for other plants (Epstein 1999; Hodson et al. 2005; Schaller et al. 2012b; Neu et al. 2017) mainly from the family of the Poaceae. However, we found large differences between the pigmented red and the non-pigmented brown rice varieties with a Si content ranging between 0.45 and $5.99 \%$ (lowest - highest $\mathrm{Si}$ availability) in red rice and 0.70 and $9.90 \%$ in brown rice depending on the Si fertilization ( $p<0.001, F=70,632$, ANOVA). This demonstrates the importance of the varieties for Si content. According to Dobermann and Fairhurst (2000), Si deficiency occurs at rice straw concentrations at maturity of less than $5 \% \mathrm{DW}^{-1}$ with an optimal range from $8-10 \%$. Because the flag leaf is a strong accumulator of $\mathrm{Si}$ we assumed that the concentrations in the whole straw were equal to the flag leaf concentrations or lower. Consequently, all plants (concentrations $<1$ to $\sim 3 \% \mathrm{DW}^{-1}$ ), except those from the Si-50 treatment (concentrations $\sim 4$ to $\sim 6 \% \mathrm{DW}^{-1}$ ) might have suffered from $\mathrm{Si}$ deficiency. Our analysis showed that the gene expression of the respective transporters was the same in seedlings of red and brown rice, indicating similar uptake of $\mathrm{Si}$. We tested the gene expression of $\mathrm{Si}$ transporters with arsenite, which is taken up via the same transporter. But, the physiological response of $\mathrm{Si}$ and arsenite are different as $\mathrm{Si}$ is known as beneficial element whereas arsenite is a toxicant. Hence, our gene expression data can provide only hints for Si uptake rates. Furthermore, the expression of the Si transporters may vary over the growth period (Yamaji and Ma 2007) with remarkably higher Si uptake during the reproductive phase (Ma et al. 1989). About $67 \%$ of all $\mathrm{Si}$ is taken up during this phase due to the high biomass production during this period. In our experiment, the $\mathrm{Si}$ concentrations in the pore water of the control, Si-1 and Si-5 treatment were below $3 \mathrm{mg} \mathrm{L}^{-1}$ during this phase, which is considerably below the optimal range of $\sim 20 \mathrm{mg} \mathrm{L}^{-1}$ for silicic acid (Savant 
et al. 1996) and consequently the tissue Si concentrations were low due to insufficient supply. The assumption of different gene expression between red and brown rice is supported by the observation that the Si concentrations in the pore water dropped stronger for the brown rice, especially noticeable in the Si-50 treatment (Fig. S2) which might indicate a higher uptake. Additionally, our analysis revealed a significantly higher Si uptake of the brown rice compared to the red rice. These differences were most pronounced in the husk where Si concentrations were about $50 \%$ higher in the brown husk compared to the red husk, even in the control. In this work, we could show that the Si concentrations in a non-pigmented brown rice variety were substantially higher than a in pigmented red rice variety.

At the FTIR-spectra around 1100, $1000 \mathrm{~cm}^{-1}$ and lower the plant biogenic silica may be seen in specific absorption features (Meyer-Jacob et al. 2014; Vogel et al. 2016). Indeed, for the samples with elevated Si content a more pronounced shoulder appeared at $1100 \mathrm{~cm}^{-1}$. With increasing Si availability (from control to Si-50) the amounts of wax and lipids $\left(2,850\right.$ to $\left.2,920 \mathrm{~cm}^{-1}\right)$, free organic acids $\left(\sim 1,710 \mathrm{~cm}^{-1}\right)$, and lignin $\left(1,650 \mathrm{~cm}^{-1}\right)$ were relatively reduced compared to carbohydrates, such as cellulose (Fig. 2). For references of the wave numbers for the different compounds see Table 1. This relative decrease in contribution of carbohydrates is not necessarily in contradiction with the reported reduction of absolute carbohydrate concentration due to increased Si content (Schoelynck et al. 2010; Schaller et al. 2012a; Klotzbücher et al. 2018). It was already suggested that Si accumulation leads to a decrease in cellulose, lignin and phenol concentrations in plants (Schoelynck et al. 2010; Schaller et al. 2012a; Klotzbücher et al. 2018). The dataset shown in this manuscript revealed that the Si effect on the content of carbon compounds is not restricted to cellulose, which was even relatively increased compared to other moieties. The effect seems much larger, leading also to a relative decreasing of other carbon compounds compared to carbohydrates, such as lignin, phenols, wax, lipids, and free organic acids.

Based on FTIR-spectra only changes in relative shares of compounds, not of absolute concentrations can be interpreted. A relative reduction in leaf wax content by increasing plant Si content would be in accordance with an earlier study showing the same reduction of wax content due to higher Si content (Agarie et al. 1998). The stronger Si effects on the amount of carbon compounds in brown compared with red rice seems to be related to the higher Si content in brown rice (Fig. 1 and 2). 


\section{Conclusions}

Silicon accumulation is known to decrease the carbon content of the aboveground tissues of plants, especially grasses like rice. Hence, Si content in plants is interfering with a large spectra of different carbon compounds potentially altering the leaf economic spectra (Wright et al. 2004) in regard to carbon quality. As the carbon quality is determining both herbivory (Awmack and Leather 2002) and organic matter decomposition (Coûteaux et al. 1995) Si content is potentially interfering with the whole ecosystem performance of grassland systems, as suggested before (Schaller et al. 2017), by e.g. increasing decomposition rate, as shown before (Schaller et al. 2014). Additionally, the differences in Si content between the different cultivars may also affect the Si cycling in grass dominated ecosystems by changing Si release during straw decomposition or from straw derived products like biochars (Schaller et al. 2018; Li et al. 2019). Furthermore, carbon can be occluded in plant Si compounds (e.g. phytolith) in the range of 0.4 to $2.8 \mathrm{mg} / \mathrm{g}$ ( $\mathrm{Li}$ et al. 2013; Song et al. 2017). The amount of carbon occluded in plant Si compounds is important for long term carbon storage in soils ( $\mathrm{Li}$ et al. 2013; Song et al. 2017). However, in regard to the amount of carbon stored in rice plant biomass, the amount of carbon occluded in plant Si compounds is less important for the carbon storage in rice plant biomass as the carbon concentration of rice plant material is $\sim 40 \%$ (Schaller et al. 2018). 


\section{Acknowledgement}

We are grateful to Johannes Stemper for help during plant cultivation, Cyrille Thomas (Centre Français du Riz) for providing the soil and discussion on cultivation practices, Stefan Will for ICP-MS and Central Analytics (all University of Bayreuth) for ICP-OES measurements. FTIR spectra were recorded at the central laboratory of the Institute of Landscape Ecology, University of Münster. The help of Henning Teickner in evaluation of FTIR spectra is greatly acknowledged. 


\section{References}

Agarie S, Uchida H, Agata W, Kubota F, Kaufman PB (1998) Effects of silicon on transpiration and leaf conductance in rice plants (Oryza sativa L.). Plant Production Science 1: 89-95.

Agethen S, Knorr K-H (2018) Juncus effusus mono-stands in restored cutover peat bogs-Analysis of litter quality, controls of anaerobic decomposition, and the risk of secondary carbon loss. Soil Biology and Biochemistry 117: 139-152.

Artz RR, Chapman SJ, Robertson AJ, Potts JM, Laggoun-Défarge F, Gogo S, Comont L, Disnar J-R, Francez A-J (2008) FTIR spectroscopy can be used as a screening tool for organic matter quality in regenerating cutover peatlands. Soil Biology and Biochemistry 40: 515-527.

Awmack CS, Leather SR (2002) Host plant quality and fecundity in herbivorous insects. Annu Rev Entomol 47: 817-844.

Bogdan K, Schenk MK (2008) Arsenic in rice (Oryza sativa L.) related to dynamics of arsenic and silicic acid in paddy soils. Environ Sci Technol 42: 7885-7890.

Broadley M, Brown P, Cakmak I, Ma JF, Rengel Z, Zhao F (2012) Chapter 8 - Beneficial Elements. In: P Marschner (ed) Marschner's Mineral Nutrition of Higher Plants (Third Edition). Academic Press, San Diego.

Cocozza C, D'orazio V, Miano T, Shotyk W (2003) Characterization of solid and aqueous phases of a peat bog profile using molecular fluorescence spectroscopy, ESR and FT-IR, and comparison with physical properties. Org Geochem 34: 49-60.

Coûteaux M-M, Bottner P, Berg B (1995) Litter decomposition, climate and litter quality. Trends Ecol Evol 10: 63-66.

da Luz BR (2006) Attenuated total reflectance spectroscopy of plant leaves: a tool for ecological and botanical studies. New Phytol 172: 305-318.

DeMaster DJ (1981) The supply and accumulation of silica in the marine environment. Geochim Cosmochim Acta 45: 1715-1732.

Dobermann A, Fairhurst T (2000) Rice: nutrient disorders \& nutrient management. Int. Rice Res. Inst. Eberle A (2015) Arsen im roten Reis der Camargue. Bayreuth.

Epstein E (1999) Silicon. Annu Rev Plant Physiol Plant Molec Biol 50: 641-664.

Hodgkins SB, Richardson CJ, Dommain R, Wang HJ, Glaser PH, Verbeke B, Winkler BR, Cobb AR, Rich VI, Missilmani M, Flanagan N, Ho M, Hoyt AM, Harvey CF, Vining SR, Hough MA, 
Moore TR, Richard PJH, De la Cruz FB, Toufaily J, Hamdan R, Cooper WT, Chanton JP (2018) Tropical peatland carbon storage linked to global latitudinal trends in peat recalcitrance. Nat Commun 9.

Hodson MJ, White PJ, Mead A, Broadley MR (2005) Phylogenetic variation in the silicon composition of plants. Ann Bot 96: 1027-1046.

Klotzbücher T, Klotzbücher A, Kaiser K, Vetterlein D, Jahn R, Mikutta R (2018) Variable silicon accumulation in plants affects terrestrial carbon cycling by controlling lignin synthesis. Glob Change Biol 24: e183-e189.

Li Z, Song Z, Cornelis J-T (2014) Impact of rice cultivar and organ on elemental composition of phytoliths and the release of bio-available silicon. Frontiers in Plant Science 5: 529.

Li Z, Song Z, Parr JF, Wang H (2013) Occluded C in rice phytoliths: implications to biogeochemical carbon sequestration. Plant Soil 370: 615-623.

Li Z, Song Z, Singh BP, Wang H (2019) The impact of crop residue biochars on silicon and nutrient cycles in croplands. Sci Total Environ 659: 673-680.

Ma J, Nishimura K, Takahashi E (1989) Effect of silicon on the growth of rice plant at different growth stages. Soil Sci Plant Nutr 35: 347-356.

Ma JF, Takahashi E (2002) Soil, fertilizer, and plant silicon research in Japan. Elsevier.

Ma JF, Tamai K, Ichii M, Wu GF (2002) A rice mutant defective in Si uptake. Plant Physiol 130: 2111-2117.

Ma JF, Tamai K, Yamaji N, Mitani N, Konishi S, Katsuhara M, Ishiguro M, Murata Y, Yano M (2006) A silicon transporter in rice. Nature 440: 688-691.

Ma JF, Yamaji N (2015) A cooperated system of silicon transport in plants. Trends Plant Sci 20: $435-442$.

Meharg C, Meharg AA (2015) Silicon, the silver bullet for mitigating biotic and abiotic stress, and improving grain quality, in rice? Environ Exp Bot 120: 8-17.

Meunier JD, Keller C, Guntzer F, Riotte J, Braun JJ, Anupama K (2014) Assessment of the 1\% $\mathrm{Na}_{2} \mathrm{CO}_{3}$ technique to quantify the phytolith pool. Geoderma 216: 30-35.

Meyer-Jacob C, Vogel H, Boxberg F, Rosén P, Weber ME, Bindler R (2014) Independent measurement of biogenic silica in sediments by FTIR spectroscopy and PLS regression. J Paleolimn 52: 245-255. 
Neu S, Schaller J, Dudel EG (2017) Silicon availability modifies nutrient use efficiency and content, $\mathrm{C}: \mathrm{N}: \mathrm{P}$ stoichiometry, and productivity of winter wheat (Triticum aestivum L.). Scientific Reports 7: 40829.

Niemeyer J, Chen Y, Bollag J-M (1992) Characterization of humic acids, composts, and peat by diffuse reflectance Fourier-transform infrared spectroscopy. Soil Sci Soc Am J 56: 135-140.

Ninno Cd, Dorosh PA (2001) Averting a food crisis: private imports and public targeted distribution in Bangladesh after the 1998 flood. Agricultural Economics 25: 337-346.

Rawsthorne S (2002) Carbon flux and fatty acid synthesis in plants. Progress in lipid research 41: 182-196.

Richmond T (2000) Higher plant cellulose synthases. Genome biology 1: reviews3001. 3001.

Samuels L, Kunst L, Jetter R (2008) Sealing plant surfaces: cuticular wax formation by epidermal cells. Annu Rev Plant Biol 59: 683-707.

Sauer D, Saccone L, Conley DJ, Herrmann L, Sommer M (2006) Review of methodologies for extracting plant-available and amorphous Si from soils and aquatic sediments. Biogeochemistry 80: 89-108.

Savant N, Snyder G, Datnoff L (1996) Silicon management and sustainable rice production. Advances in agronomy 58: 151-199.

Schaller J, Brackhage C, Dudel E (2012a) Silicon availability changes structural carbon ratio and phenol content of grasses. Environ Exp Bot 77: 283-287.

Schaller J, Brackhage C, Gessner MO, Bäuker E, Gert Dudel E (2012b) Silicon supply modifies C:N:P stoichiometry and growth of Phragmites australis. Plant Biology 14: 392-396.

Schaller J, Brackhage C, Paasch S, Brunner E, Bäucker E, Dudel EG (2013) Silica uptake from nanoparticles and silica condensation state in different tissues of Phragmites australis. Sci Total Environ 442: 6-9.

Schaller J, Hines J, Brackhage C, Bäucker E, Gessner MO (2014) Silica decouples fungal growth and litter decomposition without changing responses to climate warming and $\mathrm{N}$ enrichment. Ecology 95: 3181-3189.

Schaller J, Hodson MJ, Struyf E (2017) Is relative Si/Ca availability crucial to the performance of grassland ecosystems? Ecosphere 8: e01726. 
Schaller J, Wang J, Islam MR, Planer-Friedrich B (2018) Black carbon yields highest nutrient and lowest arsenic release when using rice residuals in paddy soils. Scientific reports 8 .

Schoelynck J, Bal K, Backx H, Okruszko T, Meire P, Struyf E (2010) Silica uptake in aquatic and wetland macrophytes: a strategic choice between silica, lignin and cellulose? New Phytol 186: $385-391$.

Snyder G (2001) Methods for silicon analysis in plants, soils, and fertilizers. Studies in Plant Science 8: $185-196$.

Song Z, Liu H, Strömberg CA, Yang X, Zhang X (2017) Phytolith carbon sequestration in global terrestrial biomes. Sci Total Environ 603: 502-509.

Vogel H, Meyer-Jacob C, Thöle L, Lippold JA, Jaccard SL (2016) Quantification of biogenic silica by means of Fourier transform infrared spectroscopy (FTIRS) in marine sediments. Limnology and oceanography: methods 14: 828-838.

Wright IJ, Reich PB, Westoby M, Ackerly DD, Baruch Z, Bongers F, Cavender-Bares J, Chapin T, Cornelissen JHC, Diemer M, Flexas J, Garnier E, Groom PK, Gulias J, Hikosaka K, Lamont BB, Lee T, Lee W, Lusk C, Midgley JJ, Navas ML, Niinemets U, Oleksyn J, Osada N, Poorter H, Poot P, Prior L, Pyankov VI, Roumet C, Thomas SC, Tjoelker MG, Veneklaas EJ, Villar R (2004) The worldwide leaf economics spectrum. Nature 428: 821-827.

Yamaji N, Ma JF (2007) Spatial distribution and temporal variation of the rice silicon transporter Lsi1. Plant Physiol 143: 1306-1313.

Zhu Y-G, Williams PN, Meharg AA (2008) Exposure to inorganic arsenic from rice: a global health issue? Environ Pollut 154: 169-171. 


\section{Figures}
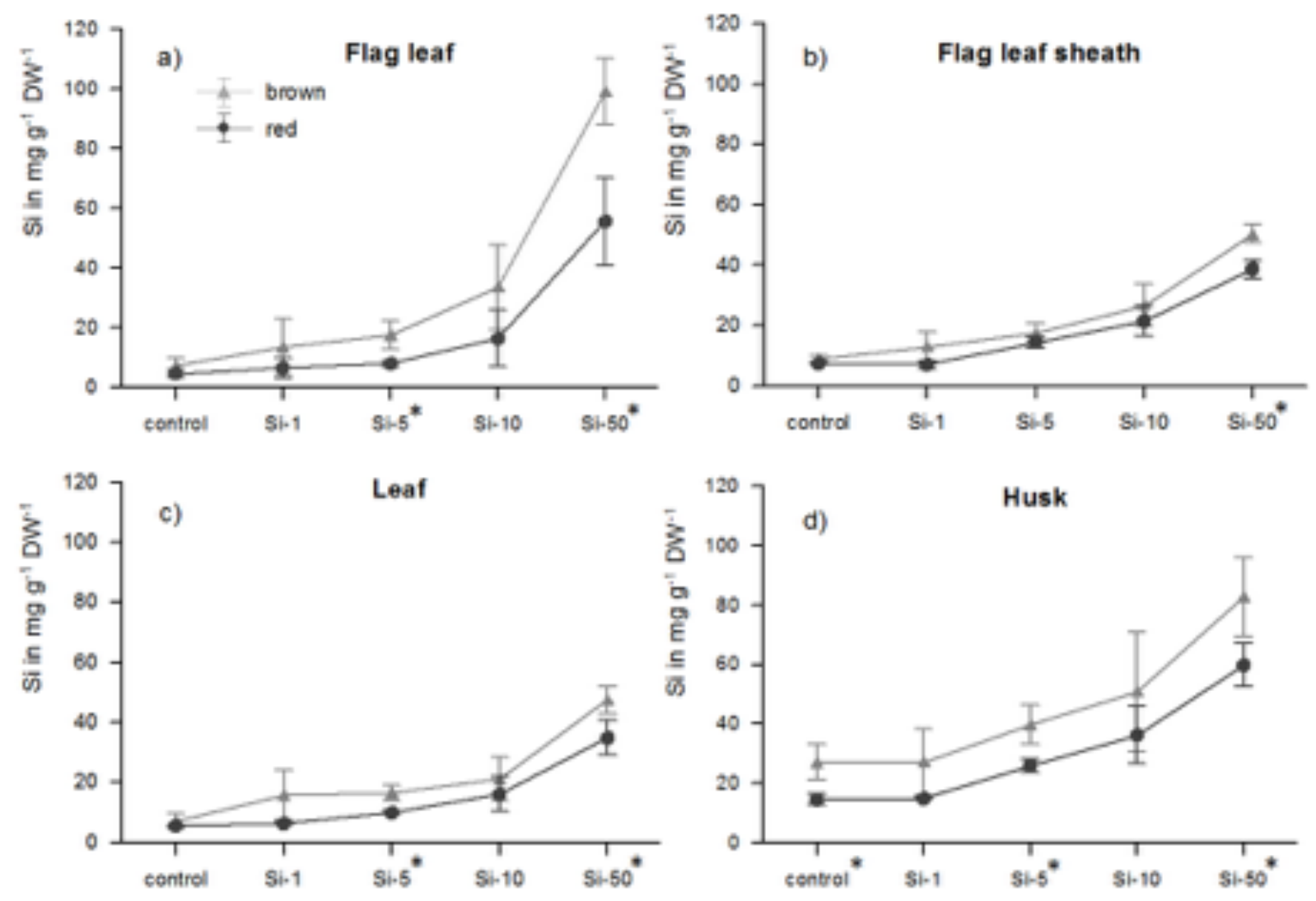

Figure 1: Mean $\pm \mathrm{SD}$ of $\mathrm{Si}$ concentration in different tissues of red and brown rice with different $\mathrm{Si}$ treatments and controls; * marks treatments with significant ( $p<0.05$, Tukey-HSD post hoc) differences between red and brown rice; $\mathrm{n}=4$. 

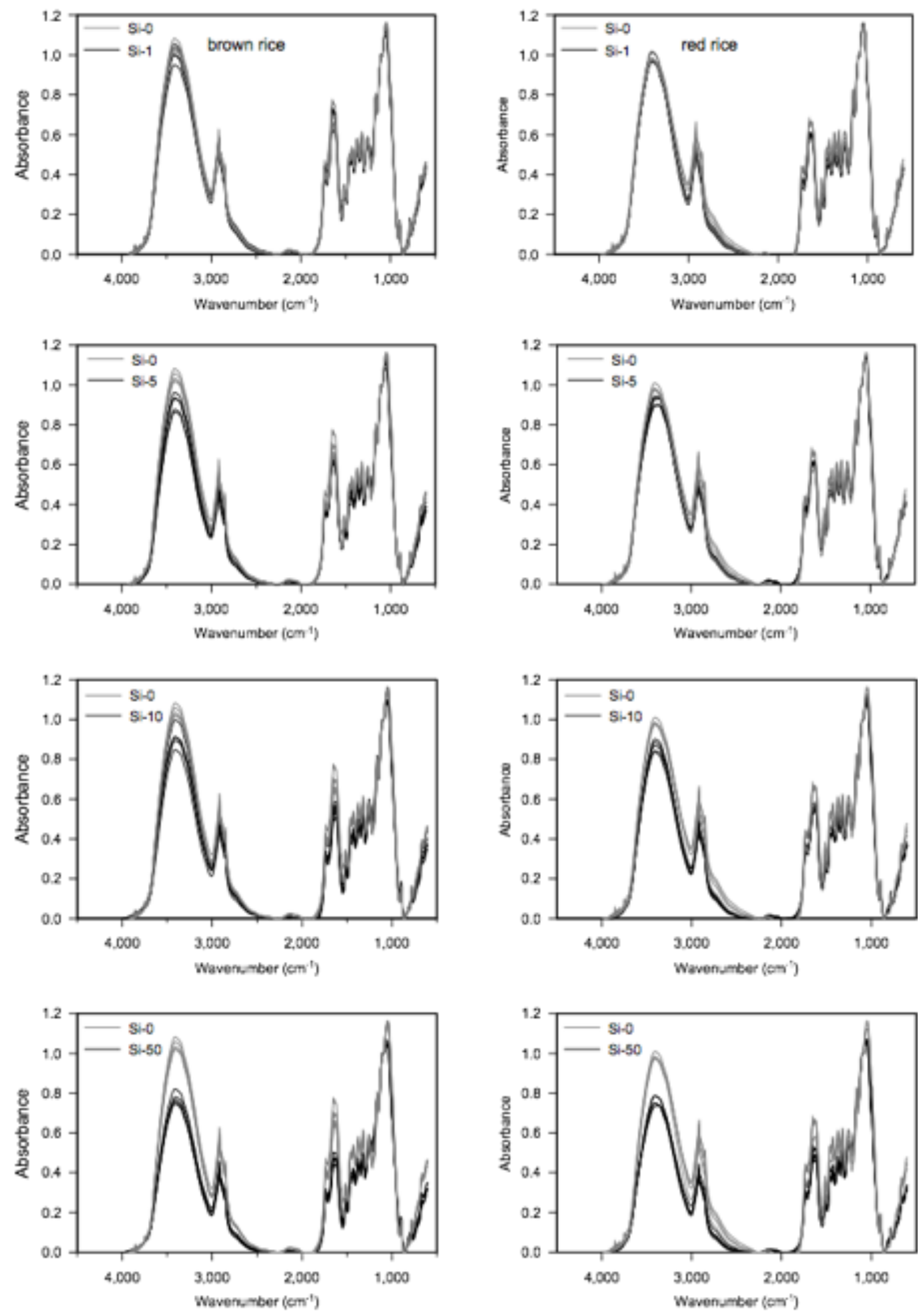

Figure 2: Magnitude of absorbance of different carbon compounds shown for red and brown rice varieties with different Si treatments and controls. $n=4$. 